\title{
THE ESSENTIAL FEATURES OF ELECTORAL PROCESS OF ARMENIA IN THE CONTEXT OF CURRENT CHANGES IN THE ELECTORAL CODE
}

\begin{abstract}
A constitutional referendum was held in Armenia on 6 December 2015. The amendments to the constitution changed the country from having a semi-presidential system to a parliamentary republic, with the changes planned to take place during the 2017-18 electoral cycle. The results of the referendum determine not only the current changes in the electoral code, but also the necessity and effectiveness of the new electoral system.

Particularly, by replacing the majoritarian system to the proportional system and by increasing the representativeness of the parliament for some groups, we can create basis for the further development of the country. Above all in the article we discussed the main factors that have a big impact on the voting behavior of the citizens.
\end{abstract}

Keywords: elections, electoral system, voter turnout, political network, clientelism, votebuying, political support.

\section{Introduction}

After the collapse of Soviet Union in 1991 lots of countries which were under the communist rule started the movements towards democracy: Armenia wasn't the exception. On September 21 Armenia declared independence and started building new democratic country after being under the Soviet dominance for seventy years.

Obviously, one of the key elements for the politics of new independent state is the good structure of the electoral system and the strong party competition. The aim of this paper is to demonstrate the electoral processes in Armenia since 1991 to contemporary time, to identify the structure of electoral system and to make the comparative analyze of the elections and their outcomes. The attention will be paid to the basic trends of electoral system reforms in the country. This work will include the main examples of Armenian elections since the independence till now and the main results will be analyzed in terms to find the negative and positive outcomes which force the states to change electoral system. This study of elections and current changes of electoral code can help us not only to find out their prospective effects on society and politics, but also to understand what challenges bring the necessity of the changes. The article will be divided in several parts starting with the theoretical part of the issue, and with the explanation of the very first independent elections and simultaneously the comparative analysis will be made with the latest elections 
to identify the reforms and development achieved since 1991.

\section{Threads of political networks, clientelism and vote-buying in elections}

The study of social networks has grown noticeably across the social and natural sciences over the past years. Both in political and social sciences articles and researches on networks were very few, but recently network theory, data and methodology are in use and very popular within researchers. Network studies cover the part of political science, that explores the effects of individuals, institutions, groups and policies through both formal and informal interaction ${ }^{1}$.

Whereas the term of "network" for a long time has been considered in political science as a way of thinking about systems of power, influence, and communication, but nowadays it becomes a formal model of political behavior. There are several factors which determine such great attention on this issue. First of all, current studies give interesting explanations of the concepts of social capital, sexual contacts, small worlds, power laws, and business success. Secondly, the social network analysis becomes somewhat more accessible due to modern computer tools.

Third, the appearance of on-line social networks attracted the attention to networks by mass media and citizens across the world. Finally, the new innovations span through formal and informal networks, which determine such huge attention on it. Gradually a number of people are involved in this topic in order to see the applicability of social net-

1 See: http://www.polinetworks.org/ works in their daily, professional, personal and political lives.

In the recent years the analysis of political and social networks becomes a basic field in the social sciences. It maintains close association with the disciplines of sociology, social psychology, political sciences, history, anthropology, even with physics. Furthermore now the network studies tend to have their own area of social experience to analyze, their own theoretical and methodological development, in some cases they have even their own conceptual schemes to formulate and test the gathered information for truth.

Indeed, recent developments show that the interest in the original literature, with studies conducted on different community samples to investigate the effect of peer networks on vote choice, social communication, expertise, and disagreement, has increased. It is then significant to know something about the structure of the social network if peer-to-peer communication affects political choices.

Taking this into consideration, we give particular attention to the fields in which social network analysis and political science are connected. Whilst some of the initial examples of empirical political science were influenced by the necessity to consider human interaction and interdependence, only recently the study of political networks was included in the mainstream political science. The concern of the gap between political science and social network analysis is that there are a lot of thrilling opportunities to reconceptualize and reanalyze the discipline with new dispositions. In addition there are essential gaps in the concepts and tools used by social network analysis that could benefit from the insight of political science, particularly in thinking abo- 
ut the meaning and consequences of power (Fowler, Heaney, Nickerson, Padgett, \& Sinclair, 2011). Yet, the investigation of social networks helps to explain why a great deal of political exchange involves neighborhood, associations and goods as a substitute to individual-level material benefits. Indeed local political brokers control the public goods. Basically the access to these local public goods plays a crucial role in political exchange, both in motivating members of neighborhood social networks to monitor each other and in ensuring that slum-level electoral support is sufficiently strong to warrant access to neighborhood-level benefits. On this terms, residents in localities have incentives to coordinate as a group and support the same candidate so that their community will be rewarded with local public goods (Rojo, Jha \& Wibbels, "Political Networks, Clientelism and Public Goods"). At the same time politicians, be an incumbent government or the opposition, wish to offer policies to groups of citizens in exchange for political support. Since the law cannot be used to compel such political exchanges, they must be self-enforcing. As has been said, citizens must indeed give their support, and politicians, once in power, must pay for the support with the policies that they promised. The politicians in order to ensure that they have the support of a group of citizens, must be able to use polices that connect the extension utility of a voter to their political success, or in their preference, if the behavior of voters is observable, let them to be punished if they deny on the exchange. On the other hand, for citizens to ensure that politicians honor their promises, the policies must be rational for the politicians to implement after elections. Overall this formulation of redistributive politics is well known as "patronage" or, more broadly, "clientelism" in anthropology and political science. Thereby the clientelism is a political exchange, when a politician (a "patron") gives patronage in exchange for the vote or support of a "client". As Weingrod articulated, "patronage refers to the way in which party politicians distribute public jobs or special favors in exchange for electoral support". If this occurs, then it can be detected that somehow the social network of individuals whose behavior politicians can observe somewhat well will determine who politicians can credibly exchange with, seemingly because they have social interactions with these individuals. Then, Turner and Young add that the "formation of a patronclient relationship is based not only on reciprocal advantage, but on some principle of affinity which supplies a social logic to the network. Kinship and ethnic affinity are the most frequent bases for network formation." Obviously, Clientelism thereafter becomes significant in countries with poor technology and high inequality. In case of low income levels of citizens, the political loyalty of clients becomes cheaper for buying with job offers, and this brings about such condition, when clientelistic redistribution is more appealing as a way of receiving support. This model can be successfully applied for the situation, when total productivity is low, or for given productivity and average income level becomes insufficient, when inequality increases. Therefore, poverty not only causes, but also is caused by clientelism. Whether there is clientelism, different factors have an impact on the size of inefficiency (Robinson, 2013).

In the present, there are small attempts to 
formulate a body of formal literature for providing the models of clientelism. One of the first authors, whose works concern these issues is Susan C. Stokes. Stokes has pointed the problem of liability of secret ballot, when voters probably can't guarantee to vote in the way they agree to in a clientelistic exchange. She tries to figure out the ways when patrons may use punishment strategies to force the voters to keep their promises and stop clients reneging on promises. Actually, vote buying let politicians and governments to ignore the interests of poor people, and in the same way it can be disruptive for the autonomy of vote sellers. Likewise, if a party wants to win enough votes to get elected at the lowest possible cost, it would start by giving the poorest person some benefits, then go on to the next one, and so on until the party has obtained just as much votes, as needed to win. The informal policy of these relations is that vote buying starts at the bottom, not the top of the income distribution. In fact the party has to increase the income distribution and each next voter's support has to be obtained at a higher price.

Hence for the long perspectives of political parties vote buying and programmatic mobilization have a lot of obstacles inasmuch they are not certain things. Moreover, the parties that give public goods and believe that they will have electoral support are acting based on their trust. In some cases when people decide to vote according to a strict calculation of costs and benefits, programmatic mobilization becomes a feeble strategy, taking into account the fact that a person's vote never change the outcome of the election and even he/she calculates the benefits of party's program whether or not he voted for it.
In general, vote buying tends to be even more uncertain offer. Meanwhile, when we speak about secret ballot, vote sellers can accept the payments and vote as they want. But then, we should find out how vote buying works. Some authors argue (Brusco, Nazareno \& Stokes, 2004) that certain kinds of parties, especially clientelist parties, can get over the secret ballot and make clear conclusions about whether people whom they "paid" actually voted for them. Indeed we can observe the structural features of clientelist parties. This kind of parties are bottom-heavy and relies on a group of local-level organizers, who live in the neighborhoods under their political responsibility, know everyone's name, know who went to the polls and who didn't, and know who was able to look them in the eye the day after the election.

The main feature of vote buying is its more finegrained targeting of benefits to similar voters. On the contrary, programmatic mobilization has capacity to reach large varieties of the electorate. Thus vote buying has advantages of correctness and leverage, but programmatic mobilization has advantages of scope. Consequently, we can find many political systems with a mix of vote buying and programmatic appeals. They also use other methods of political mobilization such as ideological, charismatic, identity-based, etc.

The main expenses of vote buying are in supporting a network of party organizers, because these people can help to reveal who has failed the deal and defected, and the costs of the items actually used to buy the vote: be the cash, the food and drink, the building materials, the articles of clothing, and so on. The expenses of the programmatic strategy are those of communicating programmatic ap- 
peals to voters: maintaining a party press, advertising, etc. Programmatic parties ought to communicate not only when they are in the opposition and want to win office, but also when they are incumbents and want to retain office. In the first case they have to inform voters about the programs they will provide if elected; in the second, they have to advertise through the programs further achievements of their tenure.

In general, party organization may play a special role in the relative advantages between vote buying and programmatic strategies. For this reason the main criterion of party organization can be the degree of centralization. In this order, the decentralized parties support personalized candidacies, which link to clientelist appeals. Likewise, decentralized, machine-like party organizations also have a higher capacity to efficiently provide goods in exchange for votes. Highly decentralized party organizations are crucial for vote buying because they are able to monitor voters and punish defectors. Overall, these organizational costs usually are higher in wealthy countries than in poor ones, based on the resources that parties have, and that's why vote buying is mainly a phenomenon of the developing world. We can also observe that the party agents, who make vote buying work, are relatively skilled people who, ultimately, find more well-paid outlets for their skills and whose work depends on country development. Once a party has ingratiated itself into local social networks, there is a definite stability to its presence in a community. Meanwhile for the party that hasn't made such investments, the costs of vote buying will be higher.
At the first glance we can conclude that the main cost for programmatic parties becomes mass communications. When the costs of broadcasting one's program is low, it's more attractive to use vote buying strategy. Currently, when higher education becomes more widespread and reachable in developing countries, the capacity of knowledge-costs decreases. In fact what parties buy is not votes but expected votes. The more becomes uncertainty, the more they tend to buy votes, consequently, both strategies can work. If a given price in a program increased the probability less of landing the vote, the effective cost of the vote per head would be higher than under vote buying. So we can assume that uncertainty of results can raise average price per vote of programmatic mobilization.

Yet we should take into consideration that the impact of constituency size on the relative costs and effectiveness of vote buying and programmatic mobilization might not be confused. On the whole, parties can control votes more easily in small communities than in large ones, because social relations in small communities are many-sided. This kind of social relations allows party operatives to know who went to the polls and who didn't.

Meanwhile, the technological features ensuring the transparency of the vote influence the effectiveness of vote buying. There are many ways to detect the votes: people can have the ballot but be forced to vote on an open table, within the range of vision of party operatives or ballots can be observable by color or by the weight of the paper; and numeric codes can allow a ballot to be identified with those individuals who cast it.

In conclusion, there are two central ideas 
in this theory. Initially the vote buying is more working strategy among voters who strongly decry programmatic promises. Their life-conditions make them prefer a less valuable reward now over a more valuable reward later. Similarly, if a voter hesitates that the future reward will materialize, he/she will prefer certain and instant payoff. Secondly, poor people used to take high discount rates and to be ambiguous about future promised benefits (Stokes, "Is Vote Buying Undemocratic?").

\section{The political situation and Historical back- ground of elections in Armenia}

Since achieving independence, Armenia has held six presidential (1991, 1996, 1998, 2003, 2008, 2013) and five parliamentary elections (1995, 1999, 2003, 2007, 2012). The president is elected for a five-year term. The National Assembly (Azgayin Zhoghov) has 131 members, elected for a four-year term, 41 members in single-seat constituencies and 90 by proportional representation. The seats envisaged for the National Assembly by proportional representation are distributed among those party lists, which have received at least $5 \%$ of the total of the number of the votes. Armenia has a multi-party system, with numerous parties in which no one party often has a chance of gaining power alone, and parties must work with each other to form coalition governments. ${ }^{2}$

The 150 members of the unicameral parliament are elected through a mixed system: 73 by two-round system in single-member constituency with majority rule and 77 by

2 See: http://www.elections.am/ proportional representation in a single nationwide constituency with an electoral threshold of $5 \%$.

Presidential elections were held for the first time in Armenia on 17 October 1991. The result was a victory for Levon TerPetrossian, who won $83 \%$ of the vote. Turnout was 70\%. On 22 September 1996 Levon Ter-Petrossian was re-elected $(51.3 \%$ of the vote, turnout was $60.3 \%$ ). Meanwhile both Ter-Petrosyan and incumbent V. Manukyan claimed victory. Official results by the Central Electoral Commission recorded Ter-Petrosyan's victory in the first round with just above $50 \%$ of the total vote in favor of the incumbent. Oppositional leader Vazgen Manukyan officially received $41 \%$ of the vote and denouncing them started mass demonstrations in the afternoon of 23 September claiming electoral fraud by Ter-Petrosyan's supporters. An estimated of 200,000 people gathered in Freedom Square to protest the election results.

On February 3 in 1998, the President of the republic Levon Ter-Petrosyan had to resign and hand over the power after agreeing to a plan to resolve the Nagorno-Karabakh conflict, which his ministers, including the Prime Minister R. Kocharyan, had refused to accept. The resignation of Levon TerPetrosyan was followed by the resignations of the NA President, Vice-Presidents, Ministers and other officials. Thus, the power was passed on to the people who govern the country today. On 16 March 1998, with a second round on 30 March, Robert Kocharyan was elected President of the Republic of Armenia in early presidential elections. He won $58.9 \%$ of the vote in the second round (turnout was $63.5 \%$ in the first round and $68.1 \%$ in the se- 
cond). Prime Minister and acting President Robert Kocharyan and Karen Demirchyan, the leader of Soviet Armenia from 1974 to 1988, won the most number of votes: $38.5 \%$ and $30.5 \%$ respectively.

Following presidential election took place in Armenia on 19 February and 5 March 2003. No candidate received a majority in the first round of the election with the incumbent President Robert Kocharyan winning slightly under $50 \%$ of the vote. Therefore, a second round was held and Kocharyan defeated Stepan Demirchyan with official results showed him winning just over $67 \%$ of the vote. However both the opposition and international observers said that the election had seen significant amounts of electoral fraud and the opposition did not recognize the results of the election.

Thereafter, the election held on 19 February 2008, resulted in Prime Minister of Armenia Serzh Sargsyan winning outright with 52.8 percent of the vote, and Ter-Pertossian gaining 21.5 percent according to official results, but this was disputed by former President Levon Ter-Petrosyan, who officially placed second. Final results, released by the Central Electoral Commission on February 24, confirmed Sargysan's victory, crediting him with $52.82 \%$ of the vote (862,369 votes), Ter-Petrosyan received $21.5 \% \quad(351,222$ votes) and Baghdasarian was said to have won $17.7 \%$ (272,427 votes).

Finally, on 18 February 2013 the Armenian citizens participated in presidential election for the sixth and last time. At the end of the election, incumbent Serzh Sargsyan was re-elected with $58.64 \%$ of the vote and Raffi Hovhannisyan received $36.74 \%$ of vote. Each of the other candidates received less the $2.2 \%$ of the vote.

Parliamentary elections to the National Assembly of the Republic of Armenia of the first convocation were held on 5 July 1995, with a second round on 29 July. There were 150 constituency seats and 40 elected on a national basis using proportional representation. The result was a victory for the Republican Bloc (an alliance of the Pan-Armenian National Movement, Democratic Liberal Party, Christian Democratic Union and the Republican Party), which won 88 of the 190 seats. Overall voter turnout was $54.3 \%$. The Republican Bloc parties ran separately in the constituency elections, with Pan-Armenian National Movement winning 62 seats, the Democratic Liberal Party winning 4, the Christian Democratic Union winning one and the Republican Party also winning one.

On May 30, 1999, the elections (131 Parliament Members: 75 majoritarian and 56 proportional electoral systems) of the National Assembly of the Republic of Armenia of the second convocation were held. The result was a victory for the Unity Bloc, which won 62 of the 131 seats. Overall voter turnout was $51.7 \%$.

The Unity Bloc was an alliance of the People's Party and the Republican Party of Armenia. According to the results of the elections, six parties and an alliance overcame the barrier of the $5 \%$ minimum vote requirement rule, as defined by the law. From the 129 Parliament Members, 76 were partisan and 53 nonpartisan (not belonging to any party).

After the crime of October 27, 1999, by the decree of the President of the Republic of Armenia, at the extraordinary sitting of the National Assembly convened on November 2, 
1999, a new governing body of the National Assembly was elected. Mr. Armen Khachatryan was elected President of the National Assembly, and Mr. Tigran Torosyan and Mr. Gagik Aslanyan were elected Vice Presidents of the National Assembly.

In the elections of the third convocation of the National Assembly held on May 30, 2003, were 56 constituency seats and 75 elected on a national basis using proportional representation. (131 Parliament Members: 75 proportional and 56 majoritarian electoral system). However, the elections were strongly criticized by international election monitors, who cited widespread fraud and noted that they fell short of democratic standards.

Elections of the fourth convocation held in Armenia on 12 May 2007(131 Parliament Members: 90 proportional and 41 majoritarian electoral system). 1,364 candidates ran for the 131 seats, 41 of which were constituency seats with the remaining 90 being filled by a proportional party-list system. Five parliamentary factions were established in the National Assembly of the Republic of Armenia of the fourth convocation: "Republican Party of Armenia" (64), "Prosperous Armenia" (25), "Armenian Revolutionary Federation" (16), "Rule of Law" (8), and "Heritage" (7). These factions were established on June 7 , 2007. Eleven Parliament Members were not included in those factions. On August 26, 2007 and on August 24, 2008, by majoritarian electoral system, additional elections were held.

And the last parliamentary elections of the fifth convocation were held on May 6, 2012 (131 Parliament Members: 90 proportional and 41 majoritarian electoral system). President Serzh Sargsyan's ruling Republican
Party gained more majority of the parliament seats. Six parliamentary factions were established in the National Assembly of the Republic of Armenia of the fifth convocation: "Republican Party of Armenia" faction (69), "Prosperous Armenia" faction (37), "Armenian National Congress" faction (7), "Rule of Law" faction (6), "Armenian Revolutionary Federation" faction (5), and "Heritage" faction (5). 2 deputies were not included in those factions. By the decree of the President of the Republic of Armenia, on April 13, 2014 Mr. Hovik Abrahamyan was appointed Prime Minister of the Republic of Armenia. Mr. Galust Sahakyan was appointed President of the National Assembly of the Republic of Armenia on April 29, 2014. ${ }^{3}$

A constitutional referendum was held in Armenia on 6 December 2015. The proposed amendments to the constitution would change the country from having a semipresidential system to being a parliamentary republic, with the changes planned to take place during the 2017-18 electoral cycle. The referendum passed with $66.2 \%$ of voters supporting it. Voter turnout was $50.8 \%$, passing the $33 \%$ threshold to validate the results. ${ }^{4}$

The new constitution of RA was adopted in July 1995 and revised in November 2005 and 2015. Constitutional reforms to change the system of government from a semipresidential to a parliamentary system were approved in a referendum in December 2015 and are set to enter force at the end of the president's term in $2018 .^{5}$

\footnotetext{
${ }^{3}$ See: http://www.parliament.am/parliament.php? id=parliament\&lang=eng

${ }^{4}$ See: http://www.lragir.am/index/eng/0/politics/ view/35046

${ }^{5}$ See: http://www.venice.coe.int/webforms/
} 
Under the amendments, Armenian National Assembly is going to consist of at least 101 deputies, instead of 131 deputies, of whom 41 are elected from single-member districts and 90 by party list. Next legislative election will take place in May 2017. The president would be head of state, embodying national unity and ensuring the observance of the Constitution. They cannot be a member of a political party. Under the proposed changes the president is to appoint a candidate for prime minister of the party of party bloc that wins parliamentary elections. If parliamentary forces are unable to agree on the candidacy of the head of government, parliament is to be dissolved. A vote of no-confidence in the prime minister can be passed no sooner than a year after their appointment. Moreover, according to electoral law, seats for ethnic minorities will be allocated.

The NA shall be elected for a five-year term in proportional only elections and President will be elected by the National Assembly for a single seven-year term. The Electoral Code shall guarantee the formation of a stable parliamentary majority. If during the first round a clear majority for a political party and stable parliamentary majority is not formed as a result of the election or by building a political coalition, then a second round of the election may be held. In case a second round is held, it shall be allowed to form new alliances. Only two parties, which would receive the most votes in the first round, would then take part in the runoff. The parties which participate in the second round of the voting are obliged to propose a candidate for Prime Min-

documents/default.asp $x$ ?pdffile $=$ CDL-

REF(2015)034-e ister and fundamentals for government's program. Furthermore, under the amendments, the NA may adopt a law on amnesty by majority vote of the total number of parliamentarians.

The constitutional reform intends a fundamental change of the government system based on a transition to a parliamentary model with strong majoritarian institutions and weak power-sharing arrangements. The suggested system will effectively promote government stability and may give stronger impetus for consolidation of political parties, but at the same time, will evidently weaken the promise of consensual governance and will result in further concentration of power and erosion of intern-institutional (horizontal) accountability and will weaken checks and balances between the government agencies. The majority of experts feared emergence of unrestrained majoritarianism as an outcome, while a considerable number of domestic experts believed that legitimization of a revived Soviet-styled "partocratic" governance would be among the most expected macro-political effects of these reforms.

Ultimately, the proposed change of government form will have intended, as well as unintended effects on consolidation of democratic institutions. The institutions of majoritarian democracy may undermine the prospect for political dialogue between different parties and social groups while strengthening the prospects for consolidation of one party dominated majoritarian rule. The extension of the list of legislation which is now to be adopted in the National Assembly by $3 / 5$ of the votes, including the so-called "organic laws", is a welcome improvement giving the parliamentary minority groups a chance to veto a lim- 
ited number of decisions that are now passed by simple majorities, but is not able to compensate for the principally ceremonial role granted to the political opposition under the proposed government model.

Thereby the next parliamentary elections will be held in Armenia in April 2017. ${ }^{6}$ They will be the first elections after the constitutional referendum in that approved reforms to become a parliamentary republic.

\section{Conclusions and considerations based on expert opinions}

\section{Methodology}

For our research topic we use the method of expert interviews. At the same time we conducted our comparative study based on the secondary analysis of existing reports and documents related to the elections of Armenia and Georgia. The experts were selected from different areas, in order to gain wide variety of opinions on issues and measures regarding to our research questions. The aim of this research is to reveal the necessity and peculiarities of changing the electoral system in Armenia and Georgia.

In addition, a survey concerning the main themes was carried out among 6 experts (academics, activists of socio-political organisations, journalists and representatives from NGOs).

\section{The socio-political situation in Armenia.}

\section{Summary of experts' comments:}

"Even though in Armenia the parliamentary elections will be held in a few months,

6 See https://news.am/eng/news/315206.html the political situation of our country is far from the so-called pre-electoral and there is an ambiguous situation when nobody knows what to expect. The authorities and party representatives haven't done any steps in order to address their political dispositions. In this case, they might appear as alliance, but still we have a huge uncertainty related to the opposition parties. The main reason of this vague situation is that we still don't have any changes in our political system. Even it is difficult to predict the polarization of the opposition. In addition, the current political situation in our country will bring us to the challenging situation, actually to the absence of any political alternatives. Thus the shape of the future parliament remains unpredictable."

"...Seemingly, the ruling party "Hanrapetakan" will take part in the elections under another name taking into consideration the negative attitudes toward the party. The main problem still remains the starting point. The second problem is that the lists included a lot of artificial people. But these patterns are not unique only for Armenia. Indeed, Armenia is much smaller, that's why the standards are much higher. The second mechanism is that the voters vote in other's names. There is also a pressure on the workers of civil services, hospitals, schools etc. For example they might be forced to vote for certain party. Here, we can emphasize also administrative recourses. I'd say that there are a lot of advantages whoever sitting on the top using networks and patronage over the acceptable stage. Unfortunately the vote buying and bribe are common in Armenia as well. The main reason and misguided perception is that "One vote can't change anything". The second is peer pressure, when we observe it in 
the villages and regions. Occasionally it becomes more dangerous, when the voters can't refuse it, because it's given by the village head. No one in the villages can contradict in such situations."

"...There is no desire among the politicians to earn the public trust. What we have, even if the new parliament is elected, it's still a parliament of individuals, much more than it's an institution. Thus, this is the lack of trust and incredibility. We can also argue that a great deal of influence on the results of elections had civic activists and observers from Armenia."

"...Therefore, in order to figure out the features of elections in Armenia, we should also examine them in the historical background. If we look at Armenian political history we can observe sudden and spontaneous behavior of voters in certain key areas. Unfortunately the parliamentary elections based on the personalities, and in terms of powersharing, it is a very difficult concept in Armenia. In this situation there are some challenges, because whoever is elected, in terms of problems, expectations and promises, this would be very difficult task for a new parliament to face all these problems and figure out the ways of solving them. People tired of the ruling party "Hanrapetakan" and I think 16year political experience approved their position. That's the main reason we have a great amount of absenteeism during the elections."

\section{Elections and electoral processes in}

\section{Armenia}

The upcoming parliamentary elections in Armenia are very important for handling the challenges of a new electoral system. It's also the first election in the new political reality. It gives an opportunity for Armenian government to resolve the internal conflicts of the country. In general, there is a huge concern about improvements of the electoral institutions. But it's crucial for Armenia, as we would see the new face of Armenian political reality. The disadvantages of it might be the situation, when we see the same faces again. So-called oligarchs can pass through these elections, which actually limit the effectiveness of a new parliament.

Compelling summary of expert opinions shows that even though there are a lot of disadvantages, but this is something new and different that we had in a past. So there is a hope for new positive changes. The reason might also depend on the new prime-minister, whom some people believe.

"...The current political situation in Armenia is somehow complicated as there is no show-up political process toward the elections. The main concern in these elections is still remains the absence of real political alternatives. There is no conflict among political parties and the oppositional parties actually don't have opportunities to win the elections at all according to the new electoral code. This is because the oppositional parties in Armenia couldn't pass the defined barrier. There is also a lack of public trust in the electoral processes. Consequently the new electoral code of Armenia should solve the problem of the trust crisis among the people."

In addition, our country decided to change the electoral code taking into account the disadvantages of current political systems. But an average voter in Armenia has historical memories from the communist Party of the Soviet Union. There is a weak party cadre, 
where too often there is a dominant party and politics in general is strongly individualized.

Political parties are faced with the common difficulties of party development even after more than two decades of communism. Furthermore, these challenges and difficulties are made by a new developing party culture. Historically, after shifting the old party a new party of power replaces it taking full control of the government.

Meanwhile, party politics especially in Armenia needs a balance of forces as in every democratic country, but the ruling party governs over 16 years. Individual parties in Armenia have mostly failed to create a sense of professionalism, regularity and diversity.

Typical opinions of experts about the current changes in electoral system.

"Although the authorities were eager to make changes in electoral code and replaced the majoritarian system to proportional, but in my opinion it has still hidden majoritarian construction. In other countries this system might be ideal, but given into consideration the traditions and behavioral models of our country, we can't insist on the fact that it's a proportional system. On the other hand the majoritarian system which is functional for another country can't be applied successfully for us. The reasons are obvious: we have oligarchic system leading us to the depth. The name of this electoral system, call them majoritarian, proportional or ranked voting system, won't change the reality of the electoral fraud. The main concern of the people is that the majoritarian system allows authorities to expand electoral fraud through bribe, networks and patronage. But this electoral system allows the community authorities form the parliament as easily, as it was before. The second problem is the construction of constituency parties, which will bring about new clans in separate districts. The following issue is that the small parties can't conquer in the elections, because they don't have as much resources, as ruling parties. It's a fact that the constitutional reforms in Armenia passed basically due to administrative resources and electoral fraud."

For upcoming elections in Armenia most of the experts were sure that the authorities should assert their positions in the parliament after elections, we won't see second round of the election, since in Armenia it usually brings to pre-revolutionary situation and they will do their best not to permit it. In comparison with Georgian elections there will be more electoral fraud, but the state officers will try to organize it before the elections and even we can observe quiet elections in Armenia.

"... The need of changes in electoral code was a must even a decade ago. But this format of changes can't create fresh political environment and fair relations. Moreover it helps the political parties to assert their positions. The parliamentary elections in Armenia usually had less importance, than the presidential elections. After each presidential election we saw mass violence. In this point of view, the authorities of our country decided to avoid of this post-electoral mess with a hope that in this case they can not only keep the power, but also ca avoid internal conflicts."

\section{REFERENCES}

Brusco, V., Nazareno, M., \& Stokes, S.C. (2004). Vote Buying in Argentina Latin American Research Review, 39(2), 66-88. 
Fowler, J.H., Heaney, M.T., Nickerson, D.W., Padgett, J.F., \& Sinclair, B. (2011). Causality in Political Networks. http://fowler.ucsd.edu/causality in $\_p$ olitical networks.pdf

Robinson, J.A. (2013). The Political Economy of Clientelism. Scandinavian Journal of Economics, 115(2), 260291. DOI: $10.1111 /$ j.14679442.2013.12010.x http://scholar.harvard.edu/files/jrobin son/files/clientelism.pdf

Rojo, G., Jha, S., \& Wibbels, E., Political Networks, Clientelism and Public Goods: https://sites.duke.edu/wibbels/files/2 014/10/Rojo_Jha_Wibbels.pdf $\% 20$

Stokes, S.C. Is Vote Buying Undemocratic? http://campuspress.yale.edu/susansto kes/files/2013/10/Is Vote Buying U ndemocratic.pdf 